\title{
An unfortunate book tour
}

\section{Who wants to live for ever?}

\section{Will Heydt-Minor}

Johnny Morton stood in the trapezoid silhouette of the New York Public Library. Four marble statues of literary figures guarded the entryway under an awning propped up by gleaming black columns. Clarke, Wells, Verne, Bulgakov, all gazing westward across the plaza and beyond. Above this was the building proper, a central stalk flanked by sloping supports. At the summit was a statue of Calliope sprawled on a golden litter.

Johnny watched the sun tumble from its noontime zenith and elongate the library's shadow, framing the muse in flaming scarlet.

He checked his watch. It was time to enter, but he couldn't bear to move. The library was simply too beautiful. Finally, he took a deep breath and walked through the bronze doors.

Inside, hundreds of people mostly older than him huddled in small groups. The interplay of hushed voices sounded like light rain on grass.

He looked up and was overcome by vertigo. The building's exterior had belied its true size. A hundred circular levels shot upwards, the hollow middle culminating in a faint green ceiling.

Suddenly a man's voice echoed in the main room.

"Welcome to this once-in-alifetime occasion!"

Immediately everyone fell silent. Johnny stood on tiptoe to see who the speaker was, but the people in front were too tall.

The voice continued: ${ }^{\alpha}$ I can think of nothing better to commemorate this new library than a rare appearance by our revered man of letters, Dr Heinrich Kravitz!"

The crowd cheered enthusiastically.

“Unfortunately, ${ }^{\circ}$ the voice added, ${ }^{\alpha}$ I can allow only a handful in at one time. Will the dosest 25 please approach? ${ }^{n}$

Johnny lowered his head and shoved through the crowd, ignoring hatefull looks and offended exhalations. A few moments later he emerged in front, just in time to join the first group.

As they walked down a hallway, he glimpsed the speaker. Curiously, the man wore a lab coat with a name-tag that read Boreal-PharmaCo.

The group arrived at a large circular room with green carpeting. The ceiling was capped by a glass dome, and in the centre, ringed by sunbeams, was a low dais. Johnny felt like he was inside an emerald.

"Have a seat my friends," their guide said softly. "Dr Kravitz will be in shortly."

Johnny found a spot near the back of the group. After a few minutes, anxious whispers began to spread through their ranks. Johnny overheard one older boy say to another, "This is his first public appearance in 40 years - maybe he's scared?"

"Maybe he's imaginary, ${ }^{\circ}$ the other replied.

Johnny snorted. They didn't know the real Heinrich Kravitz. The good doctor would show, he was sure of it.

The whispering became fully fledged conversation, then grumbling and bickering. Finally, justas someone rose to leave, the doors swung open and three men entered. The group collectively took a breath and stood up. Johnny climbed a bookshelf to get a better view. He saw Dr Kravitz being helped across

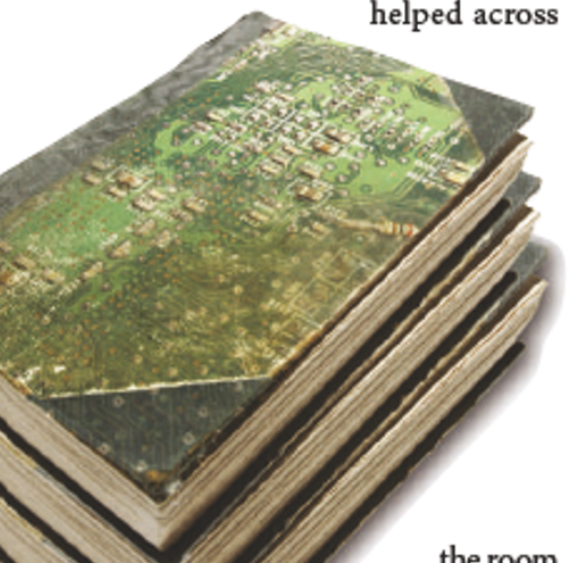
the room
by two men
in lab coats. They eased him onto the dais and retreated.

"Good day, my children," the doctor said, and the entire group exhaled and sat down. He smiled broadly. “I have written a new book about my experiences as the longest-lived man in human history, entitled Human and Trans-human. I will now read selected passages."

He cleared his throat and tilted his head upwards. ${ }^{~}$ Chapter One: the thermoplast heart is a device I postulated in my early work Alpha-Centauri or Bust! With the help of Boreal-PharmaCo it was invented two decades ago and placed inside me. In five years it will hit the market, readily available to all daring consumers. Chapter Two: the xenograft-reservoir is a device I postulated in my early work The Corona of Eternity. With the help of..."

"Wait!" Johnny called.

The entire group turned: the men in lab coats exchanged glances.

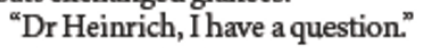

The doctor looked down and smiled. "Please, call me Henry."

${ }^{\alpha}$ Henry, wasn't your xenograft-reservoir actually in the short story Marooned!?"

The doctor was silent for a time. Then he spoke in an emotionless voice. "We hauled the body from the wreckage. Jim winced when he recognized our pilot, Smitty. 'Dammit if the old fool didn't give his all,' he whispered. I said a prayer and detached his xenograft reservoir."

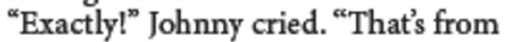
Marooned!, the first story you co-wrote with Margaretta."

The doctor stared blankly. "Who is Margaretta?"

Johnny was dumbfounded. "Why, your wife...”


the word. "My wife? My wife?"

The two men in lab coats rushed forward and seized the doctor. One of them


Kravitz is ill and needs our assistance."

The group looked around uncertainly.

"Leave!" he shouted.

They shrugged and filed out the exit. But Johnny hid behind a bookshelf and watched.

${ }^{\alpha}$ I knew this stupid thing wasn't ready for the road," the first man said.

${ }^{\alpha}$ How else were we supposed to de-bug him?" said the other.

The first detached Dr Kravitz's pate, revealing a wet grey pouch. He stuck his index finger in and swirled it around. "I knew it, that damn kid fried his back-up memory banks. This'll take months to fix."

They grabbed Dr Kravitz by the arms and unceremoniously dragged him from the room.

Meanwhile, Johnny remained hidden. Deep within he felt an odd sensation, a sort of emptiness, as ifsomething had been forcibly removed. He buried his head in his arms and swallowed a sob.

Heinrich Kravitz was dead. Will Heydt-Minor makes his home in Colorado. He writes for various Denverbased literary magazines and, together with Evan Cotageorge, publishes the science-fiction comic ADay in the Life of Theodore Welkin. He is currently seeking a degree in linguistics. 